\title{
SAR ACTION EFFECTIVENESS MEASURES
}

\section{MIARY SKUTECZNOŚCI AKCJI RATOWNICZEJ}

\author{
Zbigniew Burciu ${ }^{1}$, Andrzej Starosta ${ }^{2}$, \\ $(1,2)$ Gdynia Maritime University - Faculty of Navigation \\ Akademia Morska w Gdyni - Wydzial Nawigacyjny \\ 81-345 Gdynia, Aleja Jana Pawła II 3 \\ e-mails: (1) zbj@am.gdynia.pl, (2) andrzej.starosta@wp.pl,
}

\begin{abstract}
The paper presents the research essential to define the way of the SAR action's effectiveness measures determination. In the analyses carried out the influence of wind speed error and wind direction error as a function of the wind speed have been checked. The purpose of the second analysis was the test of the influence of the assumed errors distributions on the increase of the search area.
\end{abstract}

Keywords: SAR, search area, WDE, WSE

Streszczenie: Artykuł przedstawia badania niezbędne dla określenia sposobu wyznaczania miary skuteczności akcji ratowniczej. W przeprowadzonych analizach sprawdzono wpływ błędów prędkości i kierunku wiatru w zależności od prędkości wiatru. Druga analiza miała na celu sprawdzenie wpływu zastosowanego rozkładu błędu na przyrost obszaru poszukiwań.

Słowa kluczowe: SAR, obszar poszukiwań, WDE, WSE 


\section{SAR ACTION EFFECTIVENESS MEASURES}

\section{Effectiveness of Search and Rescue action at sea.}

Up to now in the literature we do not have a concept how to measure effectiveness of search and rescue (SAR) action. There are no indicators to show the effectiveness of SAR actions. IAMSAR (International Aeronautical and Maritime Search and Rescue) manual gives us the Probability of Success (POS) as a true measure of search effectiveness. POS is described by equation $[4,5]$ :

$$
P O S=P O C \times P O D
$$

Probability of Detection (POD) depends on technical condition of SAR units, type of SAR organization, it's readiness for the action and activities of the units and coordinator on scene.

Effectiveness of the SAR action may be decreased by improper search area determination. Large search area and limited numbers of SAR units cause the drop of action's success probability. In mathematical models of the search area some input elements are more important than others. The weights of the input element's may be determined by analysis of search area size $\left(\mathrm{S}_{\text {rect }}\right)$ and probability of containment (POC) in the search area or part of search area. The presented analyses show the influence of wind direction error and wind speed error on search areas' size.

\section{Modeling of search area}

Apart from the search object hydro-meteorological elements the main parameters of search area as follows:

- wind direction and wind direction error (WDE),

- wind speed and wind speed error (WSE).

these elements directly influence the location and the size of the search area. In the model used the search area is an ellipse described by the formula [2]:

$$
S=\pi \cdot l_{1} \cdot l_{2}
$$


where $l_{1}$ is the semi-axis of the ellipse along wind direction and $l_{2}$ is the semi-axis of the ellipse perpendicular to wind direction. Shape of search area is presented in the figure 1.

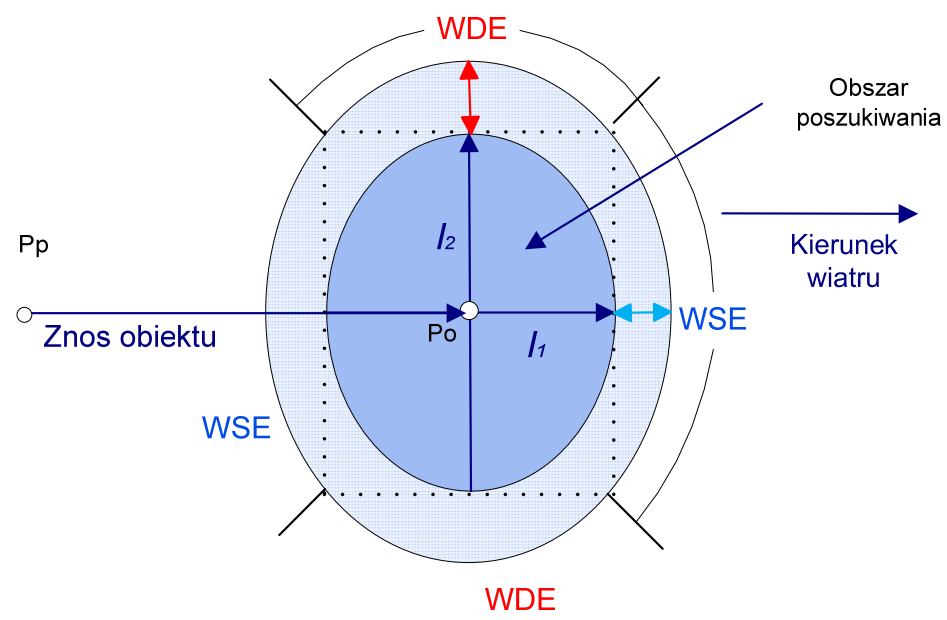

Fig. 1. Shape of search area

Dimensions of the ellipse's semi-axes, and the size of search area in the same time, depend directly on the influence of surface currents, leeway error due to life raft occupation by survivors $\left(\mathrm{B}_{\text {tr }}\right)$ and time of drift. Very important are also wind direction error (WDE) and wind speed error (WSE). With those elements ellipse's semi-axes $l_{1}$ and $l_{2}$ are described by equations:

$$
\begin{aligned}
& l_{1}(t)=\left[V_{p r}+B_{t r}\right] * t+W S E \\
& l_{2}(t)=\left[\sin \left(K_{p}-K_{w}\right) V_{p r}\right] * t+W D E
\end{aligned}
$$

where: $V_{p r}$ - current speed, $V_{w}$ - wind speed, $K p-K_{w}$ - difference between current direction and wind direction, depended on wind speed, WSE - wind speed error, $W D E$ - wind direction error, $B_{t r}$ - leeway error due to life raft loading by survivors, $t$ - time of drift.

WDE and WSE are given by the formulas:

$W D E(t)=\sin (\alpha) V_{t r} t$

$W S E(t)=0,05 \beta t$

where: $\alpha$ i $\beta$ are random variable. 


\section{Influence of WDE and WSE on the search area dimensions as a functions of wind speed}

Search area deterministic model developed at Gdynia Maritime Academy [3] was used for checking the influence of WSE and WDE on relative increase of search area's dimensions. Figures 2-4 were obtained for 10 person's life raft with drogue and 100\% load. During the calculations the wind speed was changed to obtain the influence of surface currents of 3 classes [1]. The figures present results of simulations.
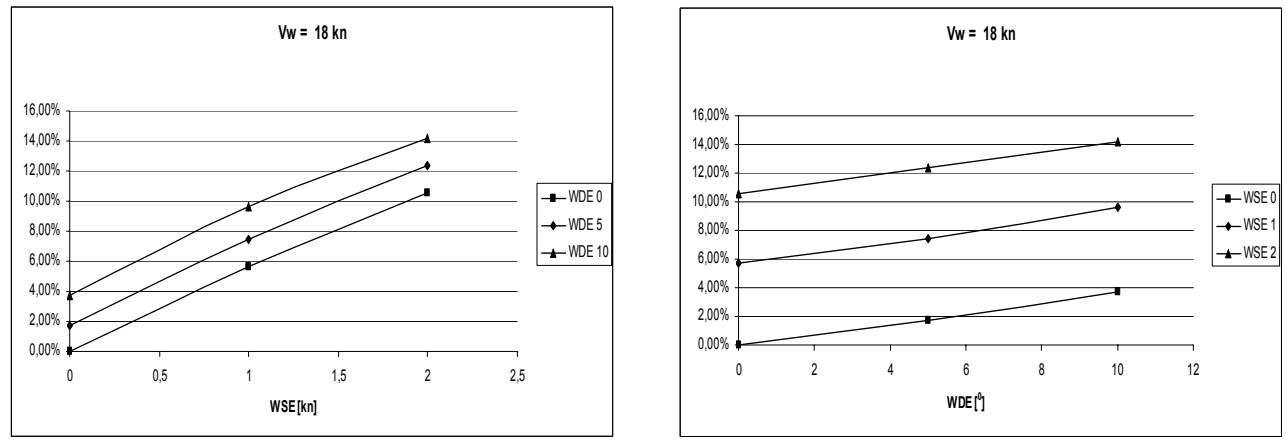

Fig. 2. Influence of WDE and WSE with class III surface currents
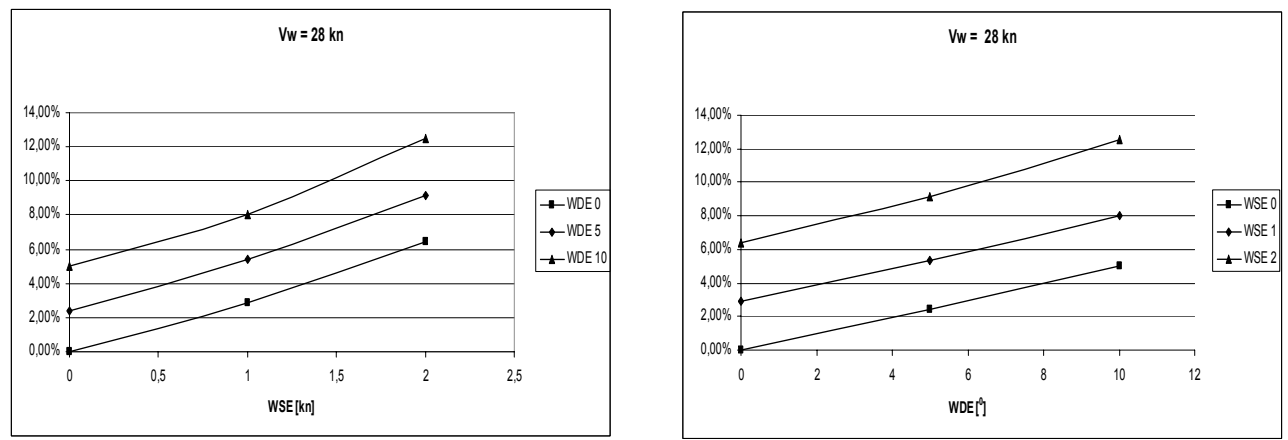

Fig. 3. Influence of WDE and WSE with class II surface currents 

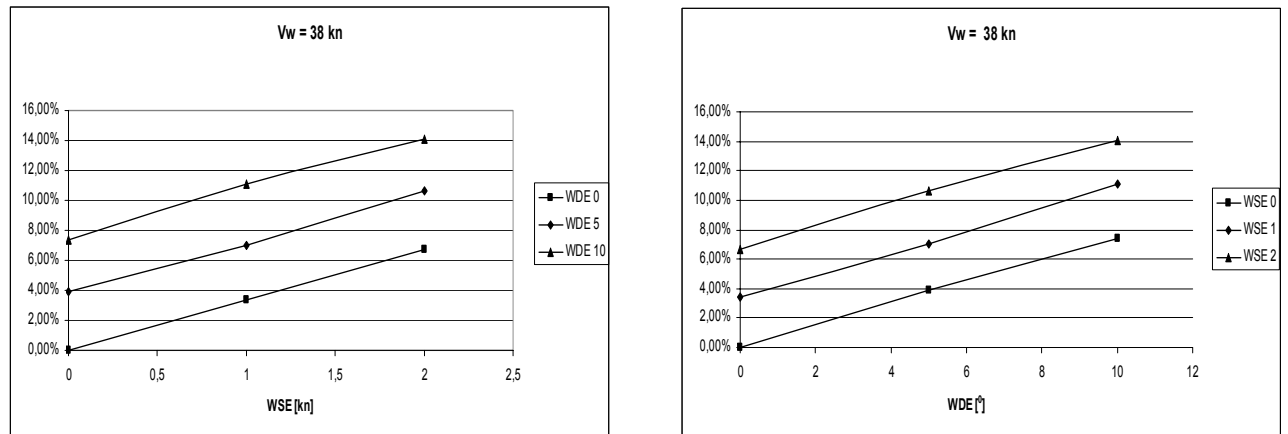

Fig. 4. Influence of WDE and WSE with class I surface currents

\section{Influence of random distribution of WDE and WSE on the search area's dimensions.}

Because the wind speed and wind direction may change a little during calculation's step of search area, Monte Carlo method was used to analyse the influence of random distribution WDE and WSE on search area's size. The model has an option to choose one of four random distributions for WDE and WSE: uniform distribution, triangle distribution, normal distribution and Laplace distribution. The distributions of the generated WSE and WDE for different random assumptions are presented in the following figures.

Histogram for wdeu

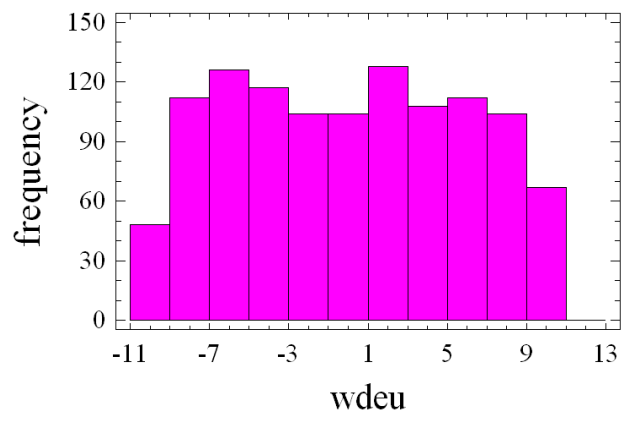

Fig. 5. WDE - uniform distribution.
Histogram for wseu

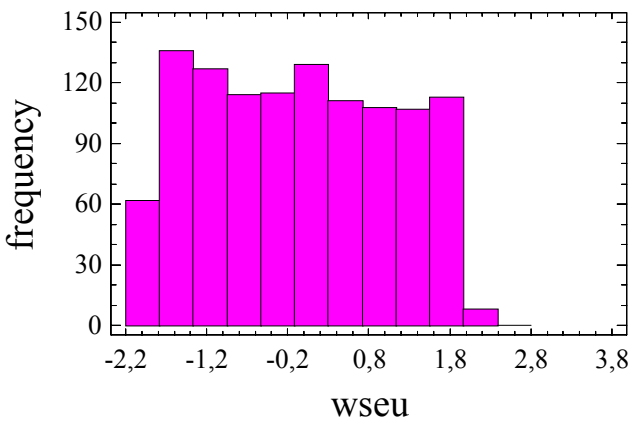

WSE - uniform distribution. 
Histogram for wset

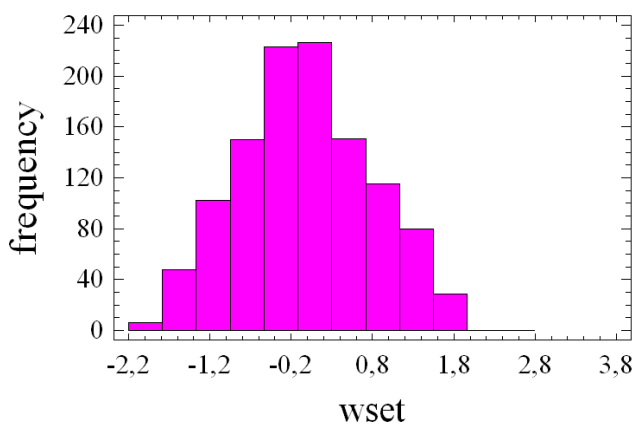

Fig.6. WSE - triangle distibution.

Histogram for wsen

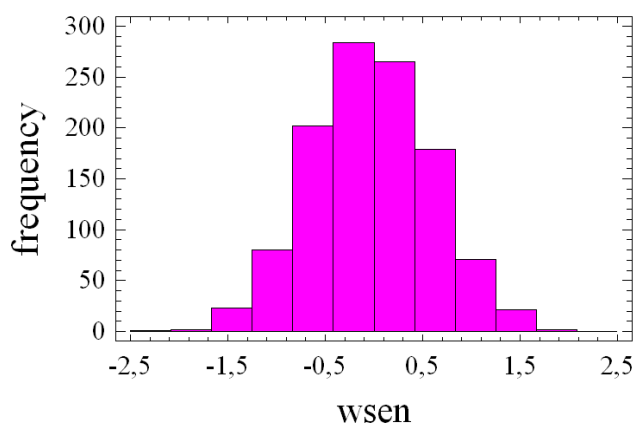

Fig. 7. WSE - normal distribution.

Histogram for wsel

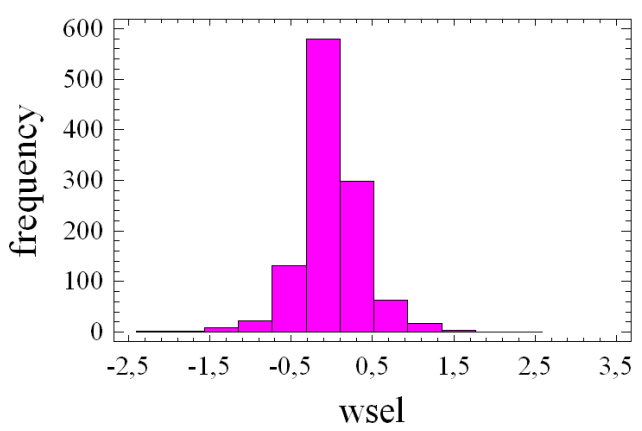

Fig. 8. WSE -Laplace distribution.
Histogram for wdet

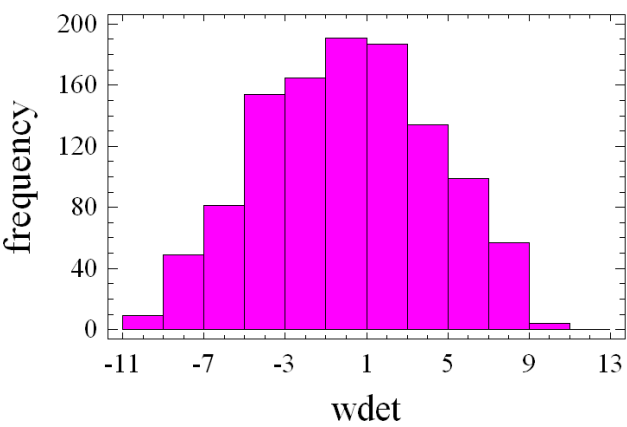

WDE - triangle distribution.

Histogram for wden

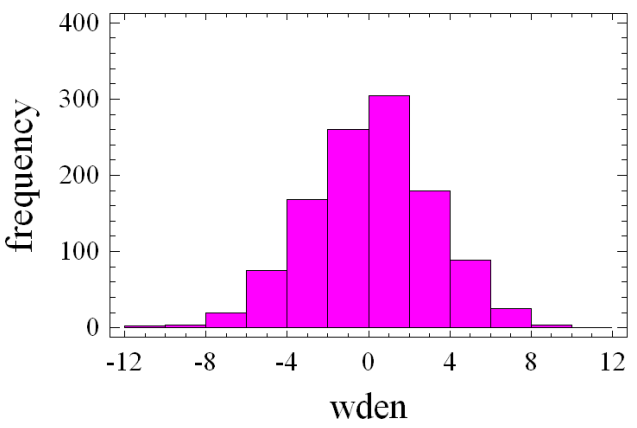

WDE - normal distribution.

Histogram for wdel

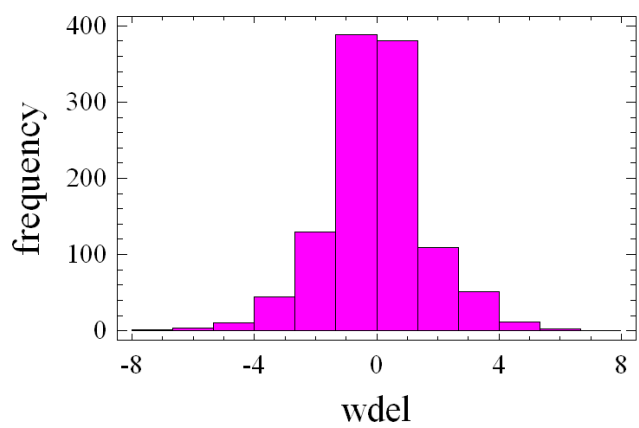

WDE -Laplace distribution. 
To analyse the influence of WDE and WSE distributions, the search area's size, based on Monte Carlo method was measured. Simulation was made for 10 person's life raft with drogue and $100 \%$ load. Errors were assumed in the range: WDE $\pm 10^{\circ}$, WSE \pm 2 knots. During the calculations wind speed was changed to obtain all 3 classes of surface currents and direction of wind was constant. Changing of search area's sizes are presented in the following figures:
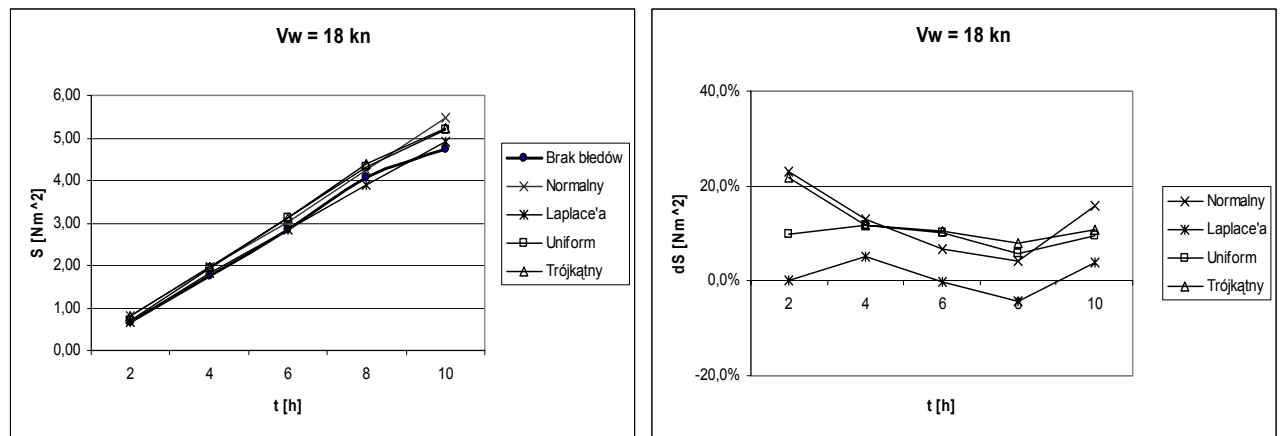

Fig. 9. Influence of random distributions of WDE and WSE with class III surface currents
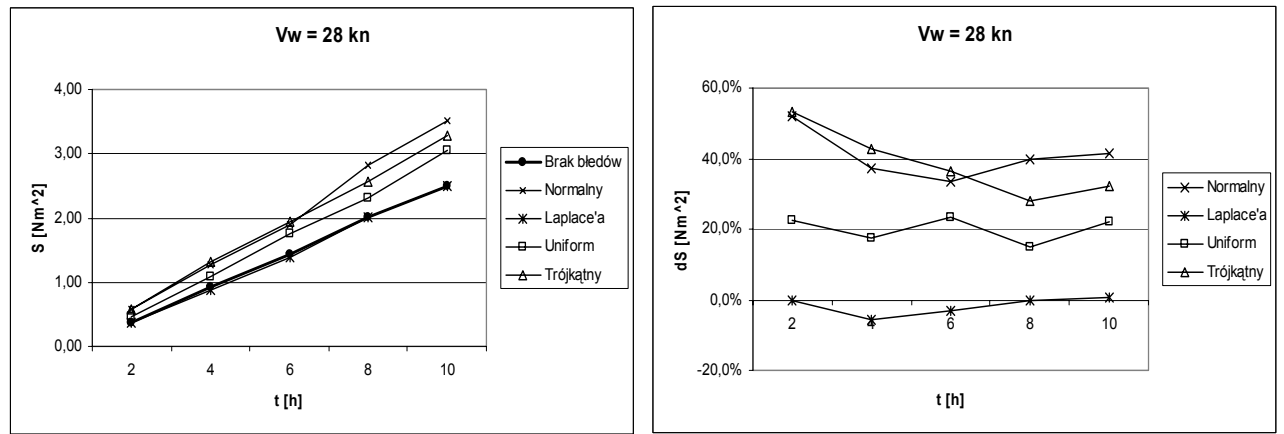

Fig. 10. Influence of random distributions of WDE and WSE with class II surface currents
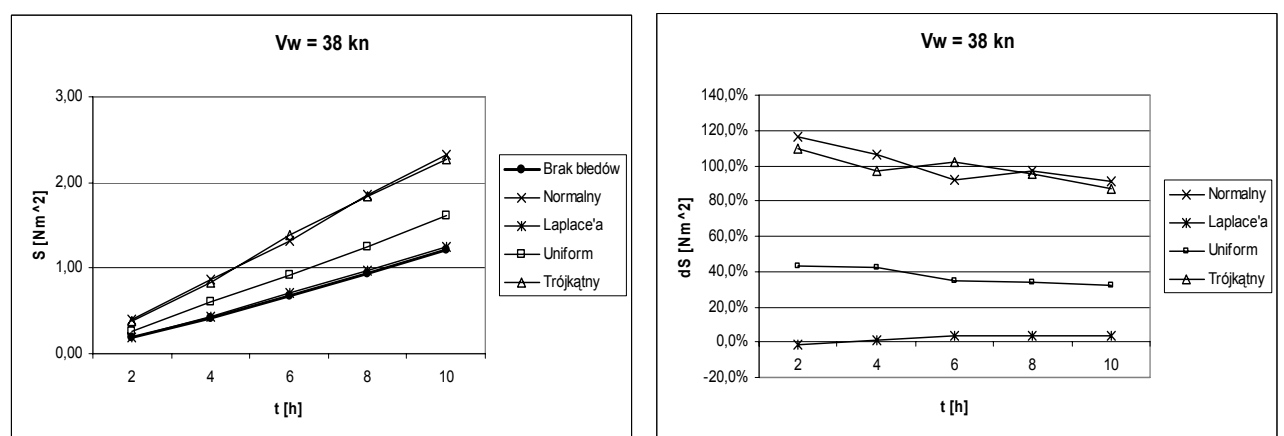

Fig. 11. Influence of random distributions of WDE and WSE with class I surface currents 


\section{Conclusions}

POC is a very important element of SAR action's effectiveness measure. POC is strongly related to the search area's size. WDE and WSE as the input parameters to the mathematical model have an important influence on the search area's size.

The presented analyses show that WSE has the biggest influence on search area when wind speed is below 18 knots and surface currents are class III. When the wind speed is around 38 knots more important is WDE. The influence of WDE and WSE is similar when surface currents are class II, although WSE has a bigger influence than WSE.

The analyses of errors random distributions influence confirmed that Laplace distributions gives the smallest changes of search area. Model has to be checked because the uniform errors gave the smaller changes that triangle and normal distributions.

To obtain the reliable SAR action's effectiveness measures it is necessary to carry on more simulations and analyses to observe the influence of other input parameters on POC and search area dimensions.

\section{References}

1. Burciu, Z. 2002. The influence of wind speed on surface water currents and its reference to search and rescue actions at sea. Archives of Transport. Volume 14, issue 2, Warsaw 2002.

2. Burciu, Z. 2003. Burciu Z Modelling of search areas in the aspect of safety of life at sea ( in Polish). Prace Naukowe, Transport, z. 50. Oficyna Wydawnicza Politechniki Warszawskiej, Warszawa 2003.

3. Burciu, Z. 2005. Sensitivity Analysis of Search Area Determination Mathematical Model. Proceedings of International Conference Maritime Transportation and Exploitation of Ocean and Coastal Resources, IMAM 2005. Lisbon 2005.

4. International Aeronautical and Maritime Search and Rescue Manual. IMO/ICAO, London/Montreal, 1999.

5. MSC/Circ.999-11 June 2001Provisions of conventions, plans, manuals and other documents affecting SAR - Changes to the IAMSAR Manual (First Edition). Proposed by the United States ICAO/IMO-JWG/7-WP.1 February, 2000. Adoption of amendments to the International Aeronautical and Maritime Search and Rescue Manual. 


\section{MIARY SKUTECZNOŚCI AKCJI RATOWNICZEJ}

\section{Skuteczność akcji ratowniczej na morzu}

W literaturze przedmiotu nie spotyka się do tej pory określenia skuteczności akcji ratowniczej. Brak jest wskaźników wyznaczających skuteczność akcji ratowniczej. IAMSAR (International Aeronautical and Maritime Search and Rescue Manual ) podaje POS (Probability of Success) jako wskaźnik określający szanse odnalezienia poszukiwanego obiektu. POS określa się jako: $[4,5]$

$$
P O S=P O C \times P O D
$$

POD (Probability of Detection) zależy od rodzaju oraz stanu technicznego jednostek ratowniczych, a także organizacji służby SAR i jej gotowość, jak i działania na miejscu akcji jednostek ratowniczych oraz koordynatora.

Skuteczność akcji może zostać obniżona poprzez niepoprawnie wyznaczony obszar poszukiwania. Zbyt duży obszar poszukiwań, przy ograniczonych środkach poszukiwawczych powoduje, że prawdopodobieństwo sukcesu akcji zostaje mocno obniżone. W danym modelu niektóre elementy wejściowe są bardziej istotne od pozostałych, przy wyznaczaniu obszaru poszukiwania. Stopień istotności elementu wejściowego można określić poprzez analizę parametrów takich jak wielkość wyznaczonego obszaru $\left(\mathrm{S}_{\text {rect }}\right)$ i prawdopodobieństwo znajdowania się obiektu poszukiwanego $\mathrm{w}$ wyznaczonym obszarze lub $\mathrm{w}$ jego wybranych podzbiorach. Przedstawione badania miały na celu określenie wpływu błędów określenia prędkości i kierunku wiatru na wielkość obszaru poszukiwań.

\section{Sposób wyznaczenia obszaru poszukiwań}

Głównymi parametrami obszaru poszukiwania oprócz obiektu poszukiwanego są elementy hydrometeorologiczne takie jak:

- kierunek wiatru i jego błąd,

- prędkość wiatru i jego błąd,

elementy te bezpośrednio wpływają na położenie i wielkość obszaru poszukiwania. W wykorzystywanym modelu jako kształt obszaru poszukiwania przyjęto elipsę o wzorze [2]: 


$$
S=\pi \cdot l_{1} \cdot l_{2}
$$

gdzie: $l_{1}$ to półoś elipsy, o kierunku zgodnym z kierunkiem wiatru, a $l_{2}$ to półoś elipsy, o kierunku prostopadłym kierunkiem wiatru. Kształt obszaru pokazuje rysunek 1 .

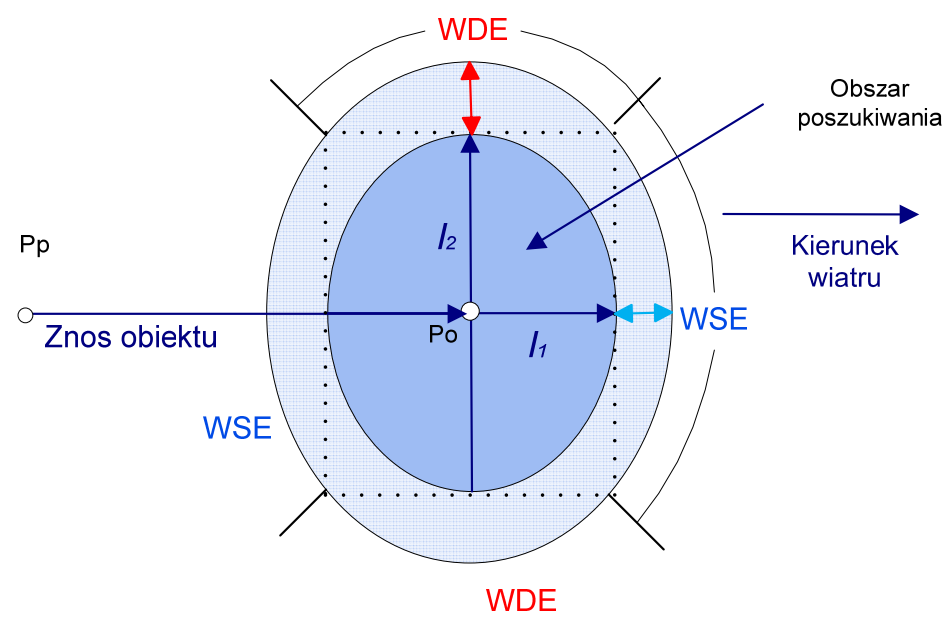

Rys. 1. Przyjęty kształt obszaru poszukiwań

Wielkość półosi elipsy, a co za tym idzie obszar poszukiwań jest zależny bezpośrednio od działania prądów przypowierzchniowych, błędu określenia prędkości znosu tratwy zależnego od stopnia obsadzenia tratwy $\left(\mathrm{B}_{\mathrm{tr}}\right)$, oraz czasu dryfu obiektu. Istotny wpływ na obliczane wielkości obszaru mają również błąd określenia kierunku wiatru (WDE) i błąd określenia jego prędkości (WSE). Przy uwzględnieniu tych parametrów półosie $l_{l}$ i $l_{2}$ obliczamy ze wzorów:

$$
\begin{aligned}
& l_{1}(t)=\left[V_{p r}+B_{t r}\right] * t+W S E \\
& l_{2}(t)=\left[\sin \left(K_{p}-K_{w}\right) V_{p r}\right] * t+W D E
\end{aligned}
$$

gdzie; $V_{p r}$ - prędkość prądu, $V_{w^{-}}$prędkość wiatru, $K p-K_{w}$ - odchylenie kierunku prądu od kierunku wiatru, zależne od prędkości wiatru, WSE- błąd prędkości wiatru, $W D E$ - błąd kierunku wiatru. $B_{t r^{-}}$błąd prędkości znosu wiatrowego tratwy, zależny od prędkości wiatru i obciążenia tratwy, $t$ - czas dryfu obiektu poszukiwanego. 
Błąd kierunku wiatru WDE i błąd prędkości wiatru WSE obliczamy ze wzorów:

$W D E(t)=\sin (\alpha) V_{t r} t$

$W S E(t)=0,05 \beta t$

gdzie $\alpha$ i $\beta$ są zmiennymi losowymi.

\section{Określenie wpływu błędów WDE i WSE ze względu na prędkość wiatru}

Korzystając z modelu deterministycznego [2] przeprowadzono symulację wpływu błędów na względny wzrost obszaru poszukiwań. Przedstawione wykresy odnoszą się do tratwy 10 osobowej z dryfkotwą obciążonej w $100 \%$. W obliczeniach zmieniano prędkość wiatru, tak aby prądy przypowierzchniowe należały do każdej z 3 klas. [1] Zachowując niezmienny jeden $\mathrm{z}$ parametrów, badano wpływ drugiego z błędów na względny przyrost pola obszaru poszukiwań. Wyniki przedstawiono na kolejnych wykresach.
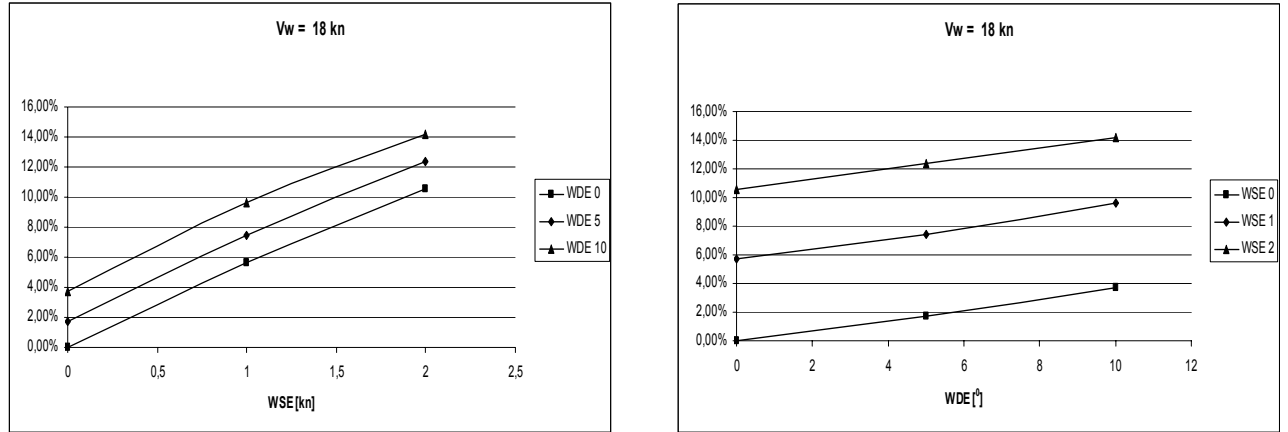

Rys. 2. Wpływ błędów WDE i WSE przy prądach klasy III
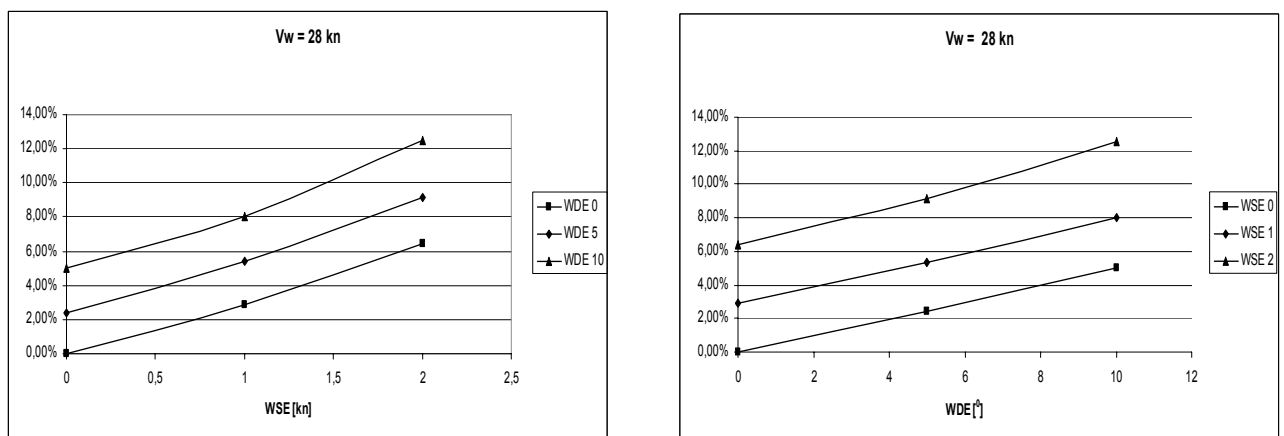

Rys. 3. Wpływ błędów WDE i WSE przy prądach klasy II 

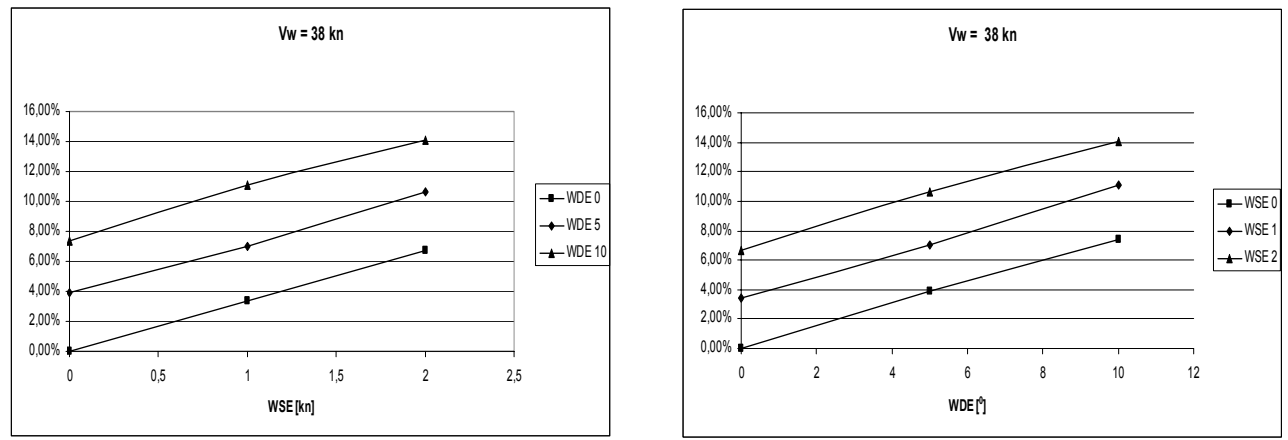

Rys.4. Wpływ błędów WDE i WSE przy prądach klasy I

\section{Wpływ zastosowanego rozkładu błędów.}

Ponieważ wartość siły i kierunku wiatru może się płynnie zmieniać podczas trwania akcji ratowniczej zastosowano metodę Monte Carlo do analizy zmian wielkości obszaru poszukiwania dla różnych rozkładów błędów WDE i WSE.

W wykorzystywanym modelu zastosowano cztery rozkłady dla wyznaczenia WDE i WSE: rozkład równomierny, rozkład trójkątny, rozkład normalny, rozkład Laplace’a. Dystrybuanty wykorzystanych rozkładów są przedstawione na kolejnych histogramach. [3] 
Histogram for wdeu

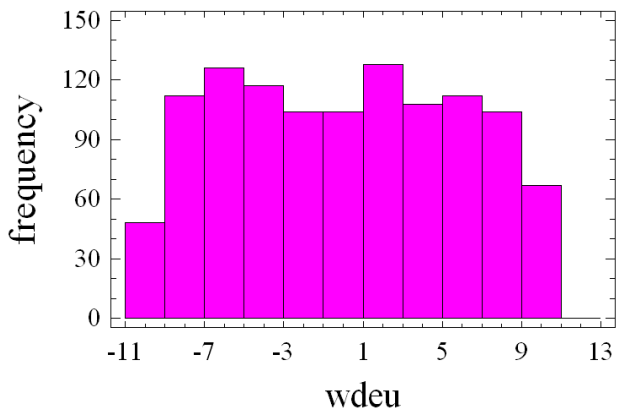

Rys 5. WDE - rozkład równomierny.

Histogram for wset

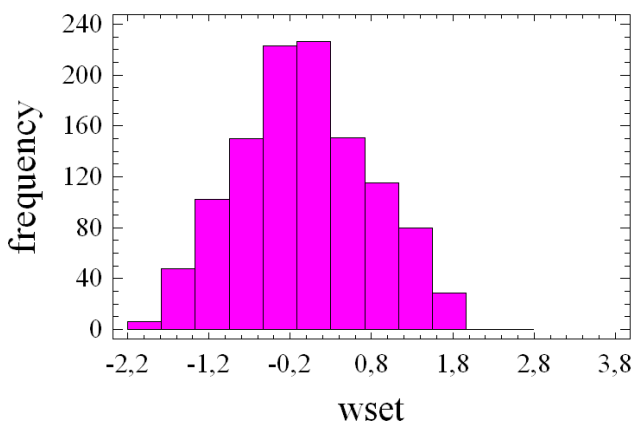

Rys.6. WSE - rozkład trójkątny.

Histogram for wsen

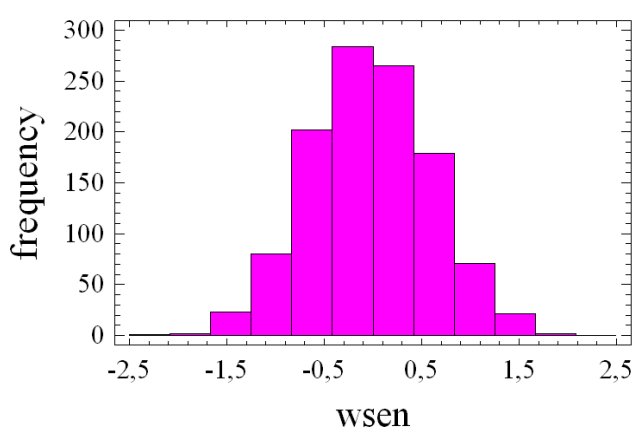

Rys. 7. WSE - rozkład normalny
Histogram for wseu

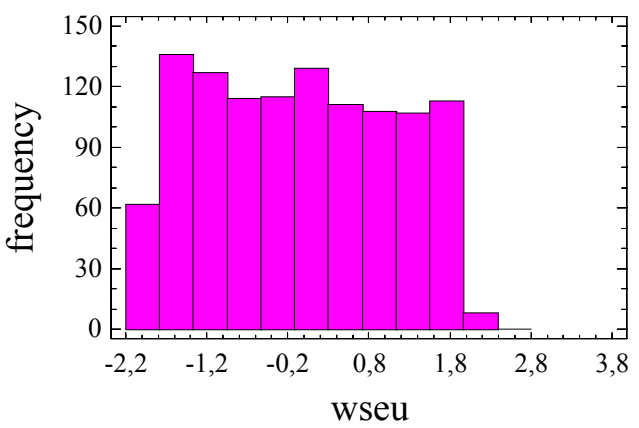

WSE - rozkład równomierny.

Histogram for wdet

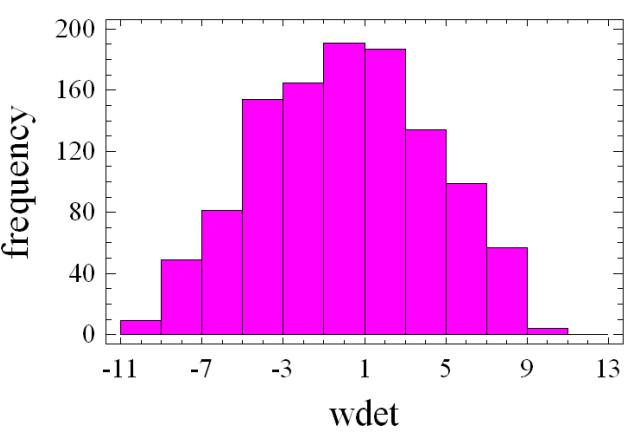

WDE - rozkład trójkątny.

Histogram for wden

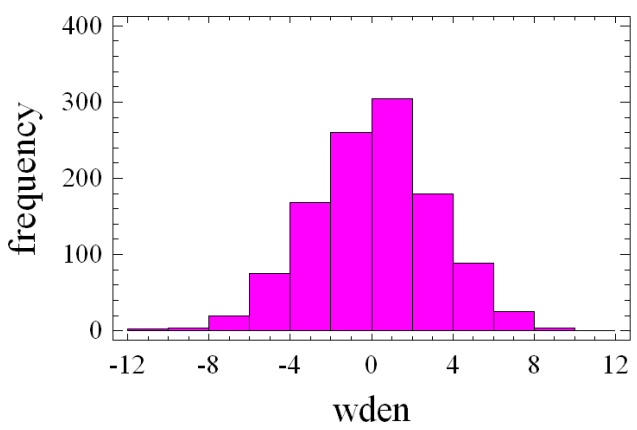

WDE - rozkład normalny. 
Histogram for wsel

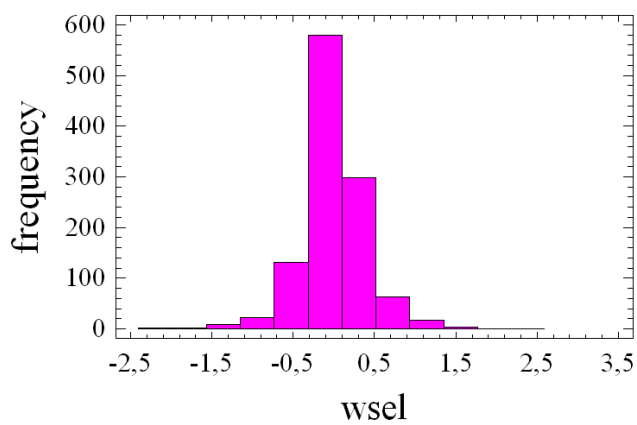

Rys. 8. WSE-rozkład Laplace.
Histogram for wdel

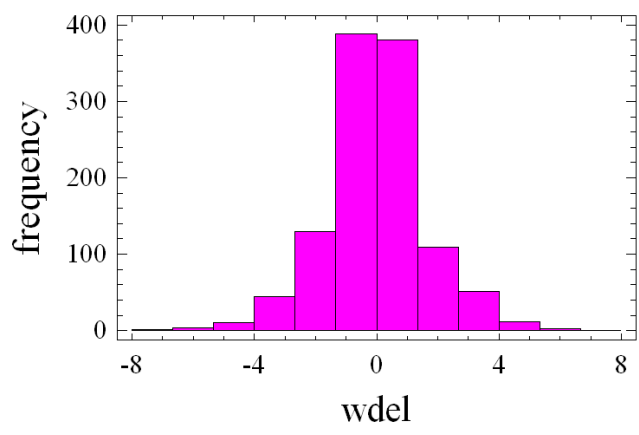

WDE - rozkład Laplace.

Przeprowadzono obliczenia pola prostokąta opartego na elipsie wyznaczonej z zastosowaniem metody Monte Carlo przy wykorzystaniu różnych rozkładów dla wyznaczenia błędów WDE i WSE. Symulację przeprowadzono dla tratwy 10 osobowej z dryfkotwą obciążonej w 100\%. Zakładane błędy mieściły się $\mathrm{w}$ granicach :WDE $\pm 10^{\circ}$, WSE \pm 2 węzły. Założono stały kierunek a prędkość wiatru zmieniano tak, aby należała, do każdej z trzech kategorii prądów przypowierzchniowych. Wyniki zmian wielkości obszaru poszukiwań w zależności od zastosowanego rozkładu prezentują kolejne wykresy.
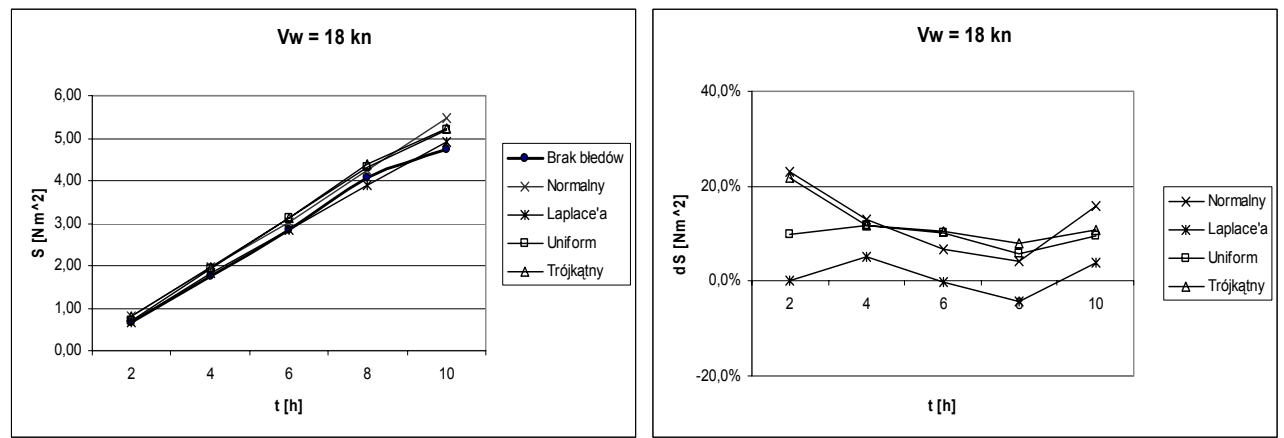

Rys. 9. Wpływ rozkładu błędów WDE i WSE przy prądach klasy III 

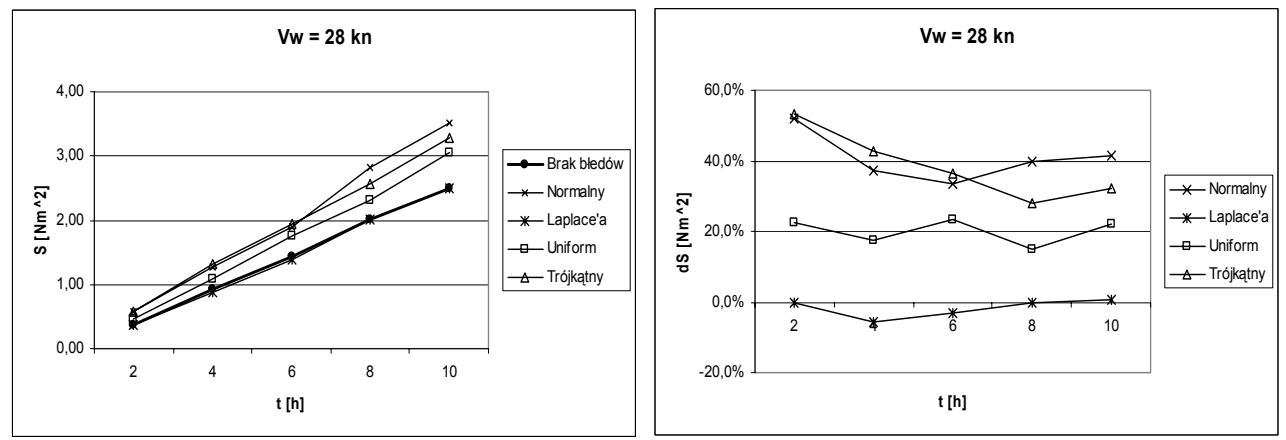

Rys. 10. Wpływ rozkładu błędów WDE i WSE przy prądach klasy II
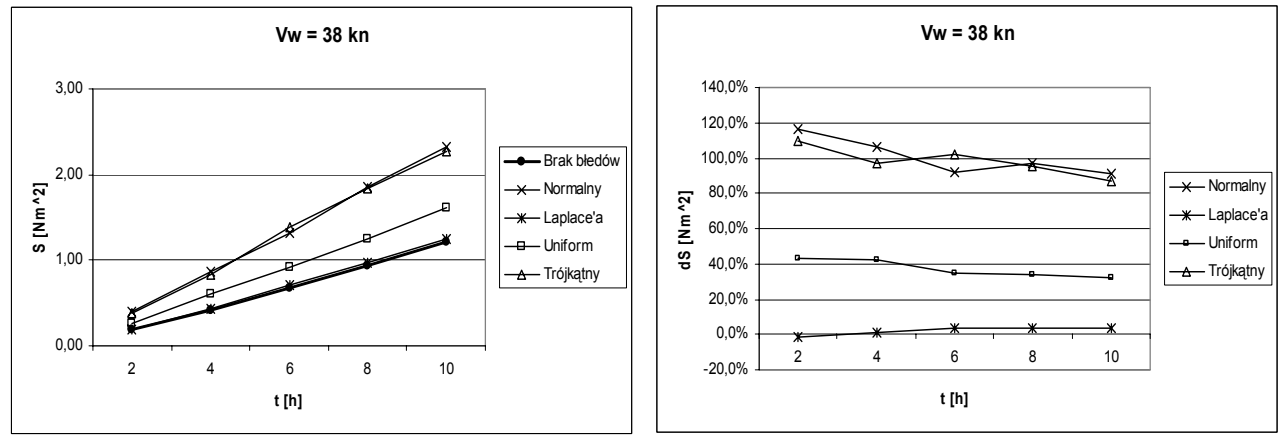

Rys. 11. Wpływ rozkładu błędów WDE i WSE przy prądach klasy I

\section{Wnioski}

Istotnym elementem miary efektywności akcji SAR jest POC, który zależy od wielkości obszaru poszukiwań. Na wielkość obszaru w znacznym stopniu oddziaływają błędy WDE i WSE, jako parametry wejściowe do modelu.

Badania wykazały, że przy niewielkim wietrze i prądach powierzchniowych klasy III większy wpływ na wzrost pola poszukiwań odgrywa WSE. Natomiast przy najsilniejszym wietrze większe znaczenie odgrywa WDE. Przy prąaach powierzchniowych klasy II wpływ błędów jest zbliżony, ale minimalnie istotniejszy jest WSE.

Badanie wpływu zastosowanego rozkładu błędu przy zastosowaniu zmiennych losowych potwierdziło, że najmniejsze odchylenia mają miejsce 
przy wykorzystaniu rozkładu Laplace'a. Zaskoczeniem jest mniejszy wpływ rozkładu równomiernego $\mathrm{w}$ porównaniu do rozkładu normalnego i trójkątnego. Wymaga to sprawdzenia zastosowanego modelu.

Określenie miar skuteczności akcji SAR wymaga jeszcze kolejnych analiz wpływu poszczególnych elementów modelu na wielkość obszaru poszukiwań i POC.

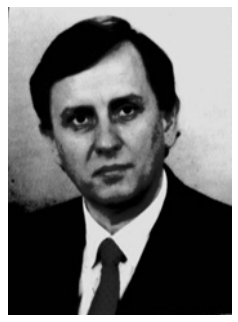

Dr hab. inż. Zbigniew Burciu, prof nadzw., is a professor of Gdynia Maritime University, D.Sc. in transport, safety and reliability in transport. V-ce Dean of Navigational Department. Main subjects of research are the maritime transport safety and Search and Rescue at Sea. Author and co-author of app.100 scientific publications in Polish and English. Master Mariner (pl. kapitan żeglugi wielkiej). 